\title{
THE GRAVITY MODEL APPROACH: AN APPLICATION ON THE ECOWAS TRADING BLOC
}

Afolabi O. Luqman, Nor Aznin Abu Bakar, Azman Aziz Mukhriz Izraf

\section{Abstract}

This study aims to examine bilateral trade flows across ECOWAS-15 nations with the use of a panel and cross section for the period of 1981-2013. The methodology carried out to achieve this objective involves the use of various techniques of estimation for the gravity model (Static and dynamic). More specifically, this study aims to investigate the formational impact of regional trade integration agreements on trade flows within a group of countries using the same currencies and ECOWAS at large. The main use of regional variables into gravity models is intended to determine whether RTAs lead to trade creation, or diversion. The results show the presence of a strong relationship among the factors of both RIAs and trade flows.

Keywords: RTAs; Trade creation and diversion; Panel Data model; Gravity models

JEL classification: $F 15, F 13, C 33, F 14$

\section{INTRODUCTION}

The fast increase of Regional Integration Aggreements (RIAs) has motivated numerous researchers to study the likely trade effects of regional integration. Since the 1990s, several RTAs have been establisehd, while some are still under negotiation. According to a trade report, as of January 2015, about 604 notifications of Regional Trade Agreements were due for implementation, while 398 were in force (WTO, 2015). Trades at the provincial level were comprehensively evaluated using the gravity model structure of international trade (Sapir 2001). Regional trade integration has turned into an issue of discussion for both non-academicians in industry, and academicians, in order to validate its existence.

ECOWAS was initiated by ECOWAS treaty in 1975. It comprises Gambia, Ghana, Burkina Faso, Cape Verde, Liberia, Guinea, Senegal, Togo, Nigeria, Niger, Guinea Bissau, Mali, Benin, Cote D'Ivoire and Sierra Leone. According to ECOWAS (2012), the population of the ECOWAS zone is around 300 million, with a GDP of approximately USD $\$ 316$ billion; the region represented

\section{Afolabi O. Luqman \\ PhD Candidate \\ School of Economics, Finance and Banking \\ UUM College of Business Universiti Utara Malaysia \\ E-mail: rskjnr001@yahoo.com \\ Nor Aznin Abu Bakar, PhD \\ Associate Professor \\ Department of Economics and Agribusiness \\ School of Economics, Finance and Banking \\ UUM College of Business Universiti Utara Malaysia \\ E-mail: noraznin@uum.edu.my \\ Azman Aziz Mukhriz Izraf, PhD \\ Senior Lecturer \\ Department of Economics and Agribusiness \\ School of Economics, Finance and Banking \\ UUM College of Business Universiti Utara Malaysia \\ E-mail:mukhriz@uum.edu.my}


about $4.5 \%$ of the world populace, but contributed to only $0.5 \%$ of the global GDP. The empirical proof indicates that higher political stability is associated with higher savings and income levels moderate the adverse effect of political instability on savings, indicating that the impact of political instability on savings is higher in low income ECOWAS countries, but lesser at higher levels of income (Abu, Mohd Zaini and Mukhriz 2014) Studies on ECOWAS regional integration have been inconclusive, as the few available ones discover either a positive effect or no effect from ECOWAS regional integration.

However, RIAs have long been acknowledged as an important way to address the concerns of the small economic magnitude of many nations, and the often subjectively strained borders that pay little heed to the dissemination of natural endowments. Based on UNCTADstat (2013), the intra-trade of ECOWAS continues to deteriorate from $10.32 \%$ in 1995 , to $6.46 \%$ in 2011 , and fnally to $7.52 \%$ in 2012 . Therefore, comparing its performance with that of other regional bodies shows that other regional bodies' trade performance was higher than that of ECOWAS (e.g., ASEAN: 24.1\%; NAFTA: $43.8 \%$; EU: $60.4 \%$ ).

The main target of this study is twofold. Our prior aim is to contribute to the methodological discussions on heteroscedasticity in various magnitude ( $i$, $\mathrm{j}, \mathrm{t})$ datasets and compare several techniques of estimations. Our second target is to critically examine the formational effect of regional integration agreements on intra-regional trade flows with the use of the gravity model on ECOWAS trade. First, in line with Vinerian specifications for determinants of either trade division or creation using the gravity model, both static and dynamic approaches are employed, such as: pool ordinary least squares (POLS), dynamic ordinary least squares (DOLS), dynamic least squares dummy variables (DLSDV), poisson pseudo maximum likelihood (PPML), and two stage least square (2sls). This article is divided into four main sections. Subdivision 1 presents the introduction to the study. Subdivision 2 determines the model specification and data used in the methodology carried out to satisfy the study's objectives. Subdivision 3 and 4 present the results, as well as conclusions with policy recommendations.

\section{METHODOLOGY}

For the purpose of this study, the gravity model was employed to estimate the bilateral trade flow among ECOWAS countries during the period of 1981-2013. In addition, theoretically grounded approaches for gravity models by Baldwin and Taglioni (2006), and
Anderson and van Wincoop (2003), were adapted for this study. Our model was specified differently from theirs, because we included the similarity size of the GDP, an absolute difference of GDP per capita, the populations of exporting and importing countries, the inflation of importing and exporting countries, and the real exchange rate among exporters and importers, as well as trade openness and FDI inflow. For the purpose of achieving this study's research objective, the following techniques were considered: pool ordinary least square (POLS), dynamic ordinary least square (DOLS), two stage least square (2SLS) and dynamic least square dummy variable (DLSDV). Based on the recommendation of Santos Silva and Tenreyro (2006), we also estimate our model using the Poisson pseudo maximum -likelihood (PPML), in order to give proper account for the patterns of heteroskedasticity characteristics in trade data, and also for the protrusion of the occurrence of zeros in most sectoral trade flow data. The model specification for bilateral trade can be defined as follows:

$$
\begin{aligned}
& \operatorname{InExp}_{i j t}=\beta_{0}+\beta_{1} \operatorname{InGDP}_{i t}+\beta_{2} \operatorname{InGDP}_{j t}+\beta_{3} \operatorname{InPOP} P_{i t} \\
& +\beta_{4} \operatorname{InPOP}_{j t}+\beta_{5} \operatorname{InDGDPPC} C_{i j t}+\beta_{6} \operatorname{InSGDP}_{i j t}+\beta_{7} \operatorname{InINF}_{I t} \\
& +\beta_{8} \text { InINF }_{j t}+\beta_{9} \text { InTradeOpen }_{i j t}+\beta_{10} \text { InFDIinflow }_{i j t} \\
& +\beta_{10} \operatorname{InDIST}_{i j t}+\beta_{11} \operatorname{InRER}_{i j t}+\beta_{12} L A N G_{i j} \\
& +\sum_{r} \alpha_{r} \text { ECOWAS.FRANCO }{ }_{i j t}+\sum_{r} \theta_{r} \text { ECOWAS.INTRA } \text { I }_{i j t}
\end{aligned}
$$



where $\mathrm{i}$ and $\mathrm{j}$ represent exporting and importing countries, $\operatorname{Exp}_{i j t}$ represents nominal export from nation i to $\mathrm{j}, D I S T_{i j t}$ is the distance between nation $\mathrm{i}$ to nation $\mathrm{j}$ (measured in kilometers), $P O P_{i t}$ represents the existing population of the exporting country for the year $\mathrm{t}, P O P_{j t}$ is the population of the importing nations, $G D P_{i t}$ is the GDP of the exporting country, $G D P_{j t}$ is the GDP for the importing countries, $R E R_{i j t}$ is the real exchange rate among exporters and importers over time, $I N F_{i t}$ is the inflation of exporting countries, $I N F_{j t}$ is the inflation of importing countries, $L A N G_{i j}$ is represented by a dummy (i.e. the country is equal to 1 if countries within ECOWAS speak the same language, otherwise 0), FDIinflow $w_{i j t}$ is the inflow of foreign direct investment within ECOWAS, and Tradeopen $n_{i j t}$ is the trade openness index measuring the level of openness of the countries within ECOWAS. SGDP $P_{i j t}$ the similarity index, which can be calculated using the size of each country pair:

$$
\begin{aligned}
& S I M G D P_{i j}^{t}=\log \left\{1-\left[G D P_{i}^{t} /\left(G D P_{i}^{t}+G D P_{j}^{t}\right)\right]^{2}\right. \\
& \left.+\left[G D P_{j}^{t} /\left(G D P_{i}^{t}+G D P_{j}^{t}\right)\right]^{2}\right\}
\end{aligned}
$$

Relative factor endowments can be captured with GDP per capita by taking the absolute difference, which are also in log form, and given as: 


\section{$D I F F G D G P P C_{i j}^{t}=\left(\ln G D P P C_{i}^{t}-\ln G D P P C_{j}^{t}\right)$}

This is represented in the model with $D G D P P C_{i j t}$, and ECOWAS. FRANCO was represented with a dummy in order to capture the impact of a group of countries using the same currencies within ECOWAS, where the exporting country dummy equals to 1 as at 1990 if it is already a member, otherwise a value of 0 is assigned. This is denoted in the model as ECOWAS. INTRA $A_{i j t}$. Furthermore, our measurement of Viner trade diversion and creation was adopted from Martinez, Zarzoso, Nowak-Lehmann, and Horsewood (2009), and Carrere (2006), which is specified as follows:

$$
\operatorname{InEXP_{ij}}=E V_{i j}+\sum_{r} \beta_{r} D_{r}+\sum_{r} \varphi_{r} D_{r i j}
$$

where $E X P_{i j t}$ represents the exports from nation $\mathrm{i}$ to nation $\mathrm{j}$ and $E V_{i j}$ represents the other explanatory variables. $D_{r}$ and $D_{r i j}$ represent the dummy variables defined in the former section as variables ECOWAS. FRANCO $_{i j t}$ and ECOWAS. intra ${ }_{i j t}$ respectively. However, Olivero and Yotov (2012) construct a theoretical basis for a dynamic setting, employing a gravity model with the use of panel data. In line with Baldwin and Taglioni (2006), the time varying effects were used to control the effect of unobservable resistance that are multilateral terms. Theoretically grounded specifications were reported with a lagged dependent variable as a regressor, contemporary and trade barrier, which are lagged. The fixed effect performs very well with time-varying types, which are directional. The dynamic model used in this study was employed by Olivero and Yotov (2012):

$$
\begin{aligned}
& \operatorname{InExp} \operatorname{Ext}_{i j}=\beta \operatorname{InExp} p_{i j_{,-1}}+\beta_{1} \operatorname{InGDP}_{i t}+\beta_{2} \operatorname{InGDP_{jt}} \\
& +\beta_{3} \operatorname{InPOP}_{i t}+\beta_{4} \operatorname{InPOP}_{j t}+\beta_{5} \operatorname{InDGDPPC} C_{i j t} \\
& +\beta_{6} I_{n S G D P} P_{i j t}+\beta_{7} \operatorname{InINF}_{I t}+\beta_{8} \text { InINF }_{j t} \\
& +\beta_{9} \text { InTradeOpen }_{i j t}+\beta_{10} \text { InFDIinflow }_{i j t} \\
& +\beta_{10} \text { InDIST }_{i j t}+\beta_{11} \text { InRER }_{i j t}+\beta_{12} L A N G_{i j} \\
& +\sum_{r} \alpha_{r} \text { ECOWAS.FRANCO } \text { Fijt }+\sum_{r} \theta_{r} \text { ECOWAS.INTRA } A_{i j t} \\
& +u_{i j t}
\end{aligned}
$$

For the purpose of comparison, suggestions from Baldwin and Taglioni (2006) were taken by including time invariant country specific-pair effects for the purpose of removing gold medal error completely. Another purpose of including a time invariant country pair effect is to take care of Nickell (1981) biases, which might occur due to the positive correlation between the lagged dependent variable and the country-pair effect, and which are unobservable. To include country-pair effects leaves distance and language to be removed or identified. Furthermore, DOLS can be used to eliminate the endogeneity bias that might result from tolerating the equation error term to be correlated with lags and leads based on the changes in the

\begin{tabular}{|c|c|c|c|c|c|c|}
\hline \multirow[b]{2}{*}{ Regressors } & \multicolumn{3}{|c|}{ Level } & \multicolumn{3}{|c|}{$\begin{array}{c}\text { First } \\
\text { differences }\end{array}$} \\
\hline & Constant & No of obs. & Trend \& Constant & No of obs & Constant & No of obs \\
\hline InExports & 60.58 & 6090 & 35.69 & 6090 & $-22.43^{* * *}$ & 5880 \\
\hline GDPSimilarity & 19.75 & 6090 & 4.74 & 6090 & $-34.92 * * *$ & 5880 \\
\hline GDPPC & 13.99 & 6090 & 20.46 & 6090 & $54.41^{* * *}$ & 5880 \\
\hline InPopulation i & 49.10 & 6090 & 79.57 & 6090 & $29.64^{* * *}$ & 5880 \\
\hline Inpopulation j & 50.93 & 6090 & 80.72 & 6090 & $-27.46^{* * *}$ & 5880 \\
\hline InTopen & 77.80 & 6090 & 94.49 & 6090 & $45.58^{* * *}$ & 5880 \\
\hline InFDlinflow & 26.93 & 6090 & 63.58 & 6090 & $29.08^{* * *}$ & 5880 \\
\hline InGDPi & 25.51 & 6090 & 39.74 & 6090 & $26.83^{* * *}$ & 5880 \\
\hline InGDPJ & 39.32 & 6090 & 25.57 & 6090 & $26.69^{* * *}$ & 5880 \\
\hline Ininflation i & 20.13 & 6090 & $69.77^{*}$ & 6090 & $42.01^{* * *}$ & 5880 \\
\hline Ininflation j & 38.01 & 6090 & $43.42^{*}$ & 6090 & $48.13^{* * *}$ & 5880 \\
\hline InReR & 22.42 & 6090 & $70.49 *$ & 6090 & $41.56^{* * *}$ & 5880 \\
\hline
\end{tabular}
stationary regressors. For generalizing purposes under a specific model to accommodate explicit effects, DOLS estimators can also be regarded to as DSLDV estimators (Mark and Saul 2003). The nations include: Gambia, Ghana, Burkina Faso, Cape Verde, Liberia,

\section{Results}

Table 1: Panel unit root result

Note: Null hypothesis testing for a unit root against the alternative in order to test the stationary of a series are computed using t-statistics (Im et al. 2003). Bayesian information criteria (BIC) are chosen as the optimal lag in most of the cases. ${ }^{* * *}$ represents a significant level of $1 \%$ 
Guinea, Senegal, Togo, Nigeria, Niger, Guinea Bissau, Mali, Benin, Cote D'Ivoire and Sierra Leone. The time period considered was 1983-2013. Bilateral exports of 15 nations were used for panel estimation, with 6510 observations $6510(15 \times 14 \times 31)$. Data were obtained from the following sources: flow of export for ECOWAS countries (denominated in US Dollars) was downloaded from the International Monetary Fund (2014), specifically under Direction of Trade Statistics. This was denoted using US producer prices $2000=$ 100. Per capita GDP and GDP variables were sourced from the World Bank Indicators Database (reported in US dollars). Time-invariant variables, which included distance and language, were downloaded from CEPII.

Based on the emerging literature on panel units and cointegration tests, variables of the gravity model were first checked before proceeding to estimate the gravity model. Numerous panel unit root tests are available. Panel variants also largely rely on whether data available for estimation is balanced or not, and also on whether cross sectional dependence and heterogeneity are allowed. Table 1 depicted above repo rts the panel unit root tests. The results indicate that all variables are integrated of order I(1), excluding real exchange and inflation, which rely on whether a deterministic trend is involved in the equation.

Table2: Kao Panel cointegration test

\begin{tabular}{llll}
\hline & Statistics & Null hypothesis & Test result \\
Kao (1997) & Panel t-statistics & No Cointegration & $-35.51018^{* * *}$ \\
\hline
\end{tabular}

The reported tests in Table 2 are less than the critical value, at a $1 \%$ level of significance, which implies a rejection of no cointegration for the null hypothesis.

Table 3: Coefficient of gravity model estimates

\begin{tabular}{|c|c|c|c|c|c|}
\hline Variables & POLS & $2 S L S$ & DOLS & PPML & DLSDV \\
\hline $\operatorname{InExp} p_{i j_{t-1}}$ & & & & & $\begin{array}{l}.497^{* * *} \\
(33.58)\end{array}$ \\
\hline GDPi & $\begin{array}{l}1.241^{* * *} \\
(11.33)\end{array}$ & $\begin{array}{l}.159 \\
(0.20)\end{array}$ & $\begin{array}{l}.193 \\
(0.54)\end{array}$ & $\begin{array}{l}.145^{* * *} \\
(11.59)\end{array}$ & $\begin{array}{l}.289 * * * \\
(3.47)\end{array}$ \\
\hline GDPj & $\begin{array}{l}.355^{* * * *} \\
(3.50)\end{array}$ & $\begin{array}{l}-5.028^{* * *} \\
(-2.96)\end{array}$ & $\begin{array}{l}.715^{* *} \\
(2.00)\end{array}$ & $\begin{array}{l}.059^{* * *} \\
(5.02)\end{array}$ & $\begin{array}{l}.184^{* *} \\
(1.98)\end{array}$ \\
\hline POPi & $\begin{array}{l}-.489^{* * *} \\
(-4.11)\end{array}$ & $\begin{array}{l}2.804^{* * *} \\
6.35\end{array}$ & $\begin{array}{l}.346 \\
(0.17)\end{array}$ & $\begin{array}{l}-.033^{* * *} \\
(-2.57)\end{array}$ & $\begin{array}{l}-.310 \\
(-0.76)\end{array}$ \\
\hline POPj & $\begin{array}{l}.450^{* * *} \\
(5.14)\end{array}$ & $\begin{array}{l}4.33^{* * *} \\
(3.80)\end{array}$ & $\begin{array}{l}-.122 \\
(-0.05)\end{array}$ & $\begin{array}{l}.0278^{* *} \\
(2.49)\end{array}$ & $\begin{array}{l}1.27^{* * *} \\
(3.05)\end{array}$ \\
\hline SGDPijt & $\begin{array}{l}-.193^{*} \\
(-1.78)\end{array}$ & $\begin{array}{l}2.454^{* *} \\
(2.30)\end{array}$ & $\begin{array}{l}-1.24^{*} \\
(-1.65)\end{array}$ & $\begin{array}{l}-.001 \\
(-0.32)\end{array}$ & $\begin{array}{l}.119 \\
(1.27)\end{array}$ \\
\hline DGDPPCij & $\begin{array}{l}.414^{* * *} \\
(5.63)\end{array}$ & $\begin{array}{l}1.093^{* * *} \\
(3.69)\end{array}$ & $\begin{array}{l}.669 * * * \\
(7.63)\end{array}$ & $\begin{array}{l}.0336^{* * *} \\
(5.45)\end{array}$ & $\begin{array}{l}.086^{* *} \\
(2.05)\end{array}$ \\
\hline INFi & $\begin{array}{l}.003 \\
(1.12)\end{array}$ & $\begin{array}{l}-.025^{* * *} \\
(-4.91)\end{array}$ & $\begin{array}{l}.039 * * * \\
(7.63)\end{array}$ & $\begin{array}{l}-.0002 \\
(-0.07)\end{array}$ & $\begin{array}{l}.003^{*} \\
(1.68)\end{array}$ \\
\hline INFj & $\begin{array}{l}.003 \\
(0.19)\end{array}$ & $\begin{array}{l}-.0009^{* * *} \\
(-2.75)\end{array}$ & $\begin{array}{l}.0006^{* *} \\
(2.15)\end{array}$ & $\begin{array}{l}.0058^{* *} \\
(2.20)\end{array}$ & $\begin{array}{l}.0009 \\
(0.65)\end{array}$ \\
\hline Distij & $\begin{array}{l}-.876^{* * *} \\
(-18.27)\end{array}$ & $\begin{array}{l}-.448^{* *} \\
(-2.50)\end{array}$ & & $\begin{array}{l}-.0738^{* * *} \\
(-18.14)\end{array}$ & \\
\hline ReRlijt & $\begin{array}{l}.014 \\
(0.30)\end{array}$ & $\begin{array}{l}-.302^{* * *} \\
(-2.78)\end{array}$ & $\begin{array}{l}-.349 * * * \\
(-4.00)\end{array}$ & $\begin{array}{l}.0033 \\
(0.80)\end{array}$ & $\begin{array}{l}-.027 \\
(-0.97)\end{array}$ \\
\hline Fdiinflowijt & $\begin{array}{l}-.0471^{*} \\
(-1.63)\end{array}$ & $\begin{array}{l}.001 * * * \\
(4.73)\end{array}$ & $\begin{array}{l}.079 * \\
(1.66)\end{array}$ & $\begin{array}{l}.0003 \\
(0.14)\end{array}$ & $\begin{array}{l}.026 \\
(1.34)\end{array}$ \\
\hline Topenijt & $\begin{array}{l}-.012^{* * *} \\
(-3.97)\end{array}$ & $\begin{array}{l}-.612^{* * *} \\
(-2.90)\end{array}$ & $\begin{array}{l}-.013^{* *} \\
(-2.26)\end{array}$ & $\begin{array}{l}-.0255^{* * *} \\
(-6.47)\end{array}$ & $\begin{array}{l}-.039 \\
(-0.97)\end{array}$ \\
\hline Langijt & $\begin{array}{l}.313^{* * *} \\
(3.68)\end{array}$ & $\begin{array}{l}-.382 \\
(-1.29)\end{array}$ & & $\begin{array}{l}.031^{* * *} \\
(4.43)\end{array}$ & \\
\hline ECOWASijt & $\begin{array}{l}-.258^{* *} \\
(-2.23)\end{array}$ & $\begin{array}{l}.500 * * * \\
(3.05)\end{array}$ & $\begin{array}{l}1.071^{* * *} \\
(4.33)\end{array}$ & $\begin{array}{l}.015 \\
(1.46)\end{array}$ & $\begin{array}{l}.037 \\
(0.40)\end{array}$ \\
\hline Eco.francoijt & $\begin{array}{l}-1.33^{* * *} \\
(-13.96)\end{array}$ & $\begin{array}{l}-.612^{* * *} \\
(-2.90)\end{array}$ & & $\begin{array}{l}-.093 * * * \\
(-10.56)\end{array}$ & \\
\hline
\end{tabular}

Note: The parentheses values are represented by t-statistics. ${ }^{*}$ denotes a significance level at $10 \%$, ${ }^{* *}$ denotes a significance level at $5 \%$, and ${ }^{* * *}$ denotes a significance level at $1 \%$. 
Thus, evidence from the panel t-test of kao (1999) indicates the presence of a cointegrating relationship among the selected variables specified for the gravity equation.

\section{INTERPRETATION OF RESULTS}

The following subsections provide an explanation and interpretation based on the results. The results shown above apply only to the period of 1983-2013; the main objective is to determine the progress of export flows among member nations within the region. The five models results are jointly presented, and include static and dynamic models. The parentheses in numbers denote the level of significance. The coefficient of lagged exports is found to be statistically significant under DLSDV at $1 \%$, signifying that adjustment plays an important part. Thus, this confirms our view that stresses that the gravity model should be considered dynamically. GDP of I to $j$ under ECOWAS is quite important for the period. The GDP elasticity shows that there is a clear market effect on trade flows within the region. The coefficient of GDPI to GDPj shows a positive sign, and was also found to be statistically significant at $1 \%$ and $5 \%$. Thus, the positive sign of the coefficient is consistent with the theoretical explanation, with the exception of GDPi, which is not significant under DOLS and $2 \mathrm{SLS}$, but still carries a positive sign. An increase in the GDPi to $\mathrm{j}$ by $1 \%$ leads to an increase of 0.15 or more on average. This result is in line with other findings (Frankel et al. 1995; Tinbergen 1962; Aitken 1973; Poyhonen 1963; Bergstrand 1985, 1989, 1990; Aitken and Obutelewicz 1976; Christerson 1994; Thursby and Thursby 1987; Geraci and Prewo 1977, 1982).

Population was introduced as a variable into the model in order to show the impact of the size of the countries involved in trade within the region. Enhancement of division of labor is determined by how large the population is, which might connote a larger domestic market. This will transform into economies of scale and other opportunities, as well as the desire to involve a variety of products. Our findings are mixed, and this is in line with previous empirical findings, including those of: Oguledo and MacPhee (1994), Linnemann (1966), and Blomqvist (1994). Matyas et al. (1997) established that trading populations of nations affected trade flow negatively and remain significant, while Brad and Mendez (1983) revealed in their findings that population size is positively significant. The coefficients of the similarity index variable are negative and significant in two of the estimates, while positive in only one. In the case of dynamic models, the similarity index was negative and significant under DOLS, while it was insignificant under DSLDV. The variations can be largely described by the heterogeneity of the countries involved in our sample. The more similar the economy of the countries in our sample is, the closer and more imperative their trade relations are. The significance level of the similarity index in POLS and DOLS is weak, which indicates that the development gaps among nations might have a restrictive influence on trade flows. As for the 2SLS model, the similarity index is positive and significant at $5 \%$. Thus, the flow of exports is largely affected by the developmental gap that existed among member nations. Trade among countries is a strong determinant of inter-industry trade. The coefficient of the distance variable maintained a negative and very significant level, both at $1 \%$ and $5 \%$. In other words, the greater the distance between countries of the region, the lesser the trade. This is in line with the classical gravity model results; an increase in the distance among countries (i.e., I to $\mathrm{j}$ ) by $1 \%$ results in the decrease on exports $0.8 \%$ on average The findings is inline with (Afolabi, Abu Bakar and Azman, 2016). The decrease is constant to all models of estimates.

Moreover, the common language coefficient is positive and significant at the $1 \%$ and $5 \%$ levels, indicating that two or more countries tend to trade more if they share a similar official language. The coefficient of the exchange rate was negative and significant in two models of our estimates. Thus, the result indicates that an appreciation of the exchange rate will tend to discourage exports from a country I to $\mathrm{j}$. The coefficient is significant at $1 \%$ and $5 \%$. This indicates that an appreciation of a real exchange rate by $1 \%$ tends to reduce country j exports by $0.3 \%$ on average. The coefficient of the real exchange is in line with the hypothesis. Meanwhile, the inflation variable of country I to $j$ shows mixed results, i.e., both negative and positive. An increase in inflation by $1 \%$ tends to reduce country j exports by $0.25 \%$ on average. This finding is in line with theoretical backing, which claims that a country with high inflation tends to experience a negative impact on export trade.

The difference in income per head based on the absolute level is significant at $1 \%$ and $5 \%$ across the model estimates. The coefficient can be interpreted in terms of related factor endowments, which was discovered to be relatively similar concerning the level of per capita income. FDI inflow is only significant in three out of the five models, including DOLS at $1 \%$ and $10 \%$. The coefficient of FDI is under 2SLS and DOLS, except for POLS, which shows a negative sign. Consequently, ECOWAS trade increases by $0.001 \%$ as FDI inflows into the region increases by $1 \%$. It was very interesting to discover that our trade openness was 
significant in four out of five estimates, but remain negative. This implies that ECOWAS country's liberal policies impede the flow of goods, thus, a decrease of $0.012 \%$ leads to a reduction in the ECOWAS trade flow by $1 \%$. Policies that will improve the free flow of goods within the region need to be implemented. The findings is inline with (Luqman, Abu Bakar and Azman, 2015)

However, it is very important to examine the coefficient of the regional group in order to access the impact of ECOWAS regional grouping preferences. ECO. Franco was introduced to investigate the impact of regional grouping on the member countries, since they are monetarily integrated, and currently use a single currency. The coefficient of the ECO. Franco variable is significant and negative, which indicates that there it is an element of trade diversion possibly among the remaining members. The coefficient of ECOWAS had on the whole unstable results for the pool OLS estimator, which shows that there is an element of trade diversion among members to outsiders. The proliferation of regional grouping has spawned much criticism. Looking forward to other estimates of ECOWAS, regional grouping as a whole shows that there is trade creation within the ECOWAS regional grouping under the 2SLS and PPML estimates. An ECOWAS member country I increases trading activities with country $j$ by $1.07 \%$ as ECOWAS trade increases by $1 \%$. The trade's improvement effect is confirmed under ECOWAS accession in two out of the three estimates. In summary, the results of the estimates indicated the significance for controlling the two main sources of endogeneity. These two sources are endogeneity that might be present mainly due to the determination of exports, as well as the I (1) explanatory variable that was determined simultaneously using a gravity model and the omitted factors that were unobservable, which might cause correlation due to endogeneity issues. This was not taken into account in previous studies.

\section{CONCLUSIONS}

The aim of this article is to explore the formational effect of regional integration agreements on intra-regional trade flows within ECOWAS. With the increasing number of RTAs, since the 1990s, the likely effect of regional trade integrations on trade flow has received increased attention. The expected positive effect of regional trade agreements among signatory nations is mostly captured with dummy variables using a gravity model framework (Greenaway and Milner 2002). However, it is of great importance to note that the implementation of RTAs does not only involve trade creation, but also causes trade diversion. With the expected trade diversion within the groups of ECOWAS nations that use the same currency, it cannot be concluded that the diversion is not with the remaining members of the group.

The extensive use of the gravity model is due to the success recorded in empirical estimates in explaining trade patterns, including its flexibility and simplicity in application. Not all empirical results that use the gravity model are reliable, as they may suffer from the problem of endogeneity bias due to some important explanatory variables. Using a panel cointegration method for estimation using the gravity model also guards against regression that is spurious. The degree of variation in our results advocates that heterogeneity is a significant aspect for gravity modeling.

Lastly, the following recommendations are provided in order to achieve better results in further studies. First, ECOWAS members should design and implement a robust industrial policy in order to expand the industrial capacity of countries and improve competitiveness. Second, a sound trade policy should be put in place in order for countries within ECOWAS to gain more from trade, which involves moving to another stage of integration in order to strengthen their performance. Third, diversification of the economy within ECOWAS should be encouraged. Fourth, a sound macroeconomic policy should be put in place. Fifth, the issue of institutions needs to address the level of development, infrastructure, and growth that must be achieved.

\section{REFERENCES}

Abu N, Karim MZA, Aziz MIA. 2014. Low savings rates in the Economic Community of West African States (ECOWAS): The role of the political instability-income interaction. South East European Journal of Economics and Business, 8(2), 53-63.

Afolabi LO, Bakar NAA, Aziz MIA. 2016. Openness And Ecowas Regional Trade: A Panel Cointegration Analysis Using A Gravity Model. Aktual'ni Problemy Ekonomiky= Actual Problems in Economics(177), 319.

Aitken ND. 1973. The effect of the EEC and EFTA on European trade: A temporal cross-section analysis. The American Economic Review, 881-892.

Aitken ND, Obutelewicz RS. 1976. A Cross-sectional Study of EEC Trade with the Association of African Countries. The Review of Economics and Statistics, 58(4), 425. doi: $10.2307 / 1935874$

Anderson J, van Wincoop E. 2001. Gravity with Gravitas: A Solution to the Border Puzzle: National Bureau of Economic Research. 
Anderson J, Yotov Y. 2012. Gold Standard Gravity: National Bureau of Economic Research.

Anderson JE, van Wincoop E. 2003. Gravity with Gravitas: A Solution to the Border Puzzle, American Economic Review. March, 93(1), 170.

Bagwell K, Staiger RW. 1998. Will preferential agreements undermine the multilateral trading system? The Economic Journal, 108(449), 1162-1182.

Baier SL, Bergstrand JH. 2007. Do free trade agreements actually increase members' international trade? Journal of International Economics, 71(1), 72-95. doi: 10.1016/j. jinteco.2006.02.005

Balassa B, Linnemann H. 1968. An Econometric Study of International Trade Flows. Econometrica, 36(2), 432. doi: $10.2307 / 1907508$

Baldwin R. 1993. A domino theory of regionalism: National Bureau of Economic Research.

Baldwin R, Taglioni D. 2006. Gravity for Dummies and Dummies for Gravity Equations: National Bureau of Economic Research.

Bergstrand, J. H. 1985. The gravity equation in international trade: some microeconomic foundations and empirical evidence. The review of economics and statistics, 474-481.

Bergstrand JH. 1989. The Generalized Gravity Equation, Monopolistic Competition, and the Factor-Proportions Theory in International Trade. The Review of Economics and Statistics, 71(1), 143. doi: 10.2307/1928061

Bergstrand JH. 1990. The Heckscher-Ohlin-Samuelson Model, The Linder Hypothesis and the Determinants of Bilateral Intra-Industry Trade. The Economic Journal, 100(403), 1216. doi: 10.2307/2233969

Bhagwati J. 1993. Regionalism and multilateralism: an overview. New dimensions in regional integration, 22, 51.

Blomqvist HC. 2004. Explaining Trade Flows of Singapore. Asian Economic Journal, 18(1), 25-43. doi: 10.1111/j.1467-8381.2004.00180.x

Brada JC, Méndez JA. 1993. Political and Economic Factors in Regional Economic Integration. Kyklos, 46(2), 183-201. doi: 10.1111/j.1467-6435.1993.tb02420.x

Bun MJ, Klaassen FJ. 2007. The Euro Effect on Trade is not as Large as Commonly Thought*. Oxford Bulletin of Economics and statistics, 69(4), 473-496.

Carrère C. 2006. Revisiting the effects of regional trade agreements on trade flows with proper specification of the gravity model. European Economic Review, 50(2), 223-247. doi: 10.1016/j.euroecorev.2004.06.001

Cheng IHW, Howard J. 1999. Controlling for Heterogeneity in Gravity Models of Trade and Integration: Inter-university Consortium for Political and Social Research (ICPSR). Retrieved from http://dx.doi.org/10.3886/icpsr01313

Christerson B. 1994. World Trade in Apparel: An Analysis of Trade Flows Using the Gravity Model. International
Regional Science Review, 17(2), 151-166. doi: 10.1177/016001769401700202

Cooper CA, Massell BF. 1965. A new look at customs union theory. The Economic Journal, 742-747.

Crawford JA, Laird S. 2001. Regional trade agreements and the WTO. The North American Journal of Economics and Finance, 12(2), 193-211. doi: 10.1016/ s1062-9408(01)00047-x

Dam KW. 1963. Regional Economic Arrangements and the GATT: The Legacy of a Misconception. The University of Chicago Law Review, 615-665.

Deardorff A. 1998. Determinants of bilateral trade: does gravity work in a neoclassical world? The regionalization of the world economy (pp. 7-32): University of Chicago Press.

Djankov S, Freund C. 2002. Trade Flows in the Former Soviet Union, 1987 to 1996. Journal of Comparative Economics, 30(1), 76-90. doi: 10.1006/jcec.2001.1752

ECOWAS. 2012. Ecowas Working With Partners To Improve Business Climate In West Africa Retrieved 10/2/2015,2015,http://news.ecowas.int/presseshow. php.

ECOWAS. 2012.ECOWAS:Ministerial Meeting. Africa Research Bulletin: Political, Social and Cultural Series, 49(9), 19407A-19408B. doi: 10.1111/j.1467-825x.2012.04676.x

Egger P, Pfaffermayr M. 2004. Distance, trade and FDI: a Hausman-Taylor SUR approach. Journal of Applied Econometrics, 19(2), 227-246.

Endoh M. 1999. Trade creation and trade diversion in the EEC, the LAFTA and the CMEA: 1960-1994. Applied Economics, 31(2), 207-216. doi: 10.1080/000368499324435

Evenett S, Keller W. 1998. On Theories Explaining the Success of the Gravity Equation: National Bureau of Economic Research.

Feenstra R, Kee HL. 2004. Export Variety and Country Productivity: National Bureau of Economic Research.

Frankel J, Stein E, Wei SJ. 1995. Trading blocs and the Americas: The natural, the unnatural, and the super-natural. Journal of Development Economics, 47(1), 61-95. doi: 10.1016/0304-3878(95)00005-4

García EC, Navarro Pabsdorf M, Gómez Herrera E. 2013. The gravity model analysis: an application on MERCOSUR trade flows. Journal of Economic Policy Reform, 16(4), 336-348. doi: 10.1080/17487870.2013.846857

Geraci VJ, Prewo W. 1977. Bilateral Trade Flows and Transport Costs. The Review of Economics and Statistics, 59(1), 67. doi: $10.2307 / 1924905$

Geraci VJ, Prewo W. 1982. An Empirical Demand and Supply Model of Multilateral Trade. The Review of Economics and Statistics, 64(3), 432. doi: 10.2307/1925941

Greenaway D, Milner C. 2002. Regionalism and Gravity. Scottish J Political Economy, 49(5), 574-585. doi: 10.1111/1467-9485.00249 
Grossman GM, Helpman E. 1993. The politics of free trade agreements: National Bureau of Economic Research.

Gruber WH, Vernon R. 1970. The technology factor in a world trade matrix The technology factor in international trade (pp. 233-302): UMI.

Hanson G, Xiang C. 2002. The Home Market Effect and Bilateral Trade Patterns: National Bureau of Economic Research.

Heckscher EF, Ohlin BG. 1991. Heckscher-Ohlin trade theory: The MIT Press.

Helpman E. 1987. Imperfect competition and international trade: Evidence from fourteen industrial countries. Journal of the Japanese and international economies, $1(1), 62-81$.

Helpman E, Krugman PR. 1985. Market structure and foreign trade: Increasing returns, imperfect competition, and the international economy: MIT press.

Helpman E, Melitz M, Rubinstein Y. 2007. Estimating trade flows: Trading partners and trading volumes: National Bureau of Economic Research.

Hsu L. 2006. Applicability of WTO Law in Regional Trade Agreements: Identifying the Links Regional Trade Agreements and the WTO Legal System (pp. 525-552): Oxford University Press (OUP).

Hummels D, Levinsohn J. 1993. Monopolistic competition and international trade: reconsidering the evidence: National Bureau of Economic Research.

Im KS, Pesaran MH, Shin Y. 2003. Testing for unit roots in heterogeneous panels. Journal of econometrics, 115(1), 53-74.

Im KS, Pesaran MH, Shin Y. 2003. Testing for unit roots in heterogeneous panels. Journal of Econometrics, 115(1), 5374. doi: 10.1016/s0304-4076(03)00092-7

Kahouli B, Maktouf S. 2013. Regional Trade Agreements in Mediterranean Area: Econometric Analysis by Static Gravity Model. Journal of East-West Business, 19(4), 237259. doi: 10.1080/10669868.2013.794380

Kahouli B, Maktouf S. 2014. The link between regional integration agreements, trade flows and economic crisis. International Journal of Development Issues, 13(1), 3558. doi: 10.1108/ijdi-11-2013-0082

Kahouli B, Maktouf S. 2015. Trade creation and diversion effects in the Mediterranean area: Econometric analysis by gravity model. The Journal of International Trade \& Economic Development, 24(1), 76-104.

Kao C. 1999. Spurious regression and residual-based tests for cointegration in panel data. Journal of Econometrics, 90(1), 1-44. doi: 10.1016/s0304-4076(98)00023-2

Krishna P. 1998. Regionalism and multilateralism: A political economy approach. Quarterly Journal of Economics, 227-251.

Laaser CF, Schrader K. 2005. Baltic Trade with Europe: Back to the Roots? Baltic Journal of Economics, 5(2), 15-37. doi: 10.1080/1406099x.2005.10840421
Lee H, Park I. 2007. In Search of Optimised Regional Trade Agreements and Applications to East Asia. The World Economy, 30(5), 783-806. doi: 10.1111/j.1467-9701.2007.01024.x

Leibenstein H, Tinbergen J. 1966. Shaping the World Economy: Suggestions for an International Economic Policy. The Economic Journal, 76(301), 92. doi: $10.2307 / 2229041$

Levy PI. 1997. A political-economic analysis of free-trade agreements. The American Economic Review, 506-519.

Linder SB. 1961. An essay on trade and transformation: Wiley.

Linnemann H. 1966. An econometric study of international trade flows (Vol. 234): North-Holland Publishing Company Amsterdam.

Lipsey RG. 1960. The theory of customs unions: A general survey. The Economic Journal, 496-513.

Liu Q, Sun B, Yan H, Lu L. 2015. A Model of Anomaly Discovery. Int. finance discuss. pap., 2015(1128), 1-45. doi: 10.17016/ifdp.2015.1128

Luqman O, Bakar A, Aznin N, Aziz A, Izraf M. 2015. Regionalism and ECOWAS Trade Performance: A Gravity Model Approach. Bogazici Journal: Review of Social, Economic \& Administrative Studies, 29(2).

Mark NC, Sul D. 2003. Cointegration Vector Estimation by Panel DOLS and Long-run Money Demand*. Oxford Bulletin of Economics and Statistics, 65(5), 655-680. doi: 10.1111/j.1468-0084.2003.00066.x

Martínez-Zarzoso I, Felicitas NLD, Horsewood N. 2009. Are regional trading agreements beneficial? The North American Journal of Economics and Finance, 20(1), 4665. doi: 10.1016/j.najef.2008.10.001

Matyas L. 1997. Proper Econometric Specification of the Gravity Model. The World Economy, 20(3), 363-368. doi: 10.1111/1467-9701.00074

Narayan PK, Smyth R. 2008. Energy consumption and real GDP in G7 countries: new evidence from panel cointegration with structural breaks. Energy Economics, 30(5), 2331-2341.

Nickell S. 1981. Biases in Dynamic Models with Fixed Effects. Econometrica, 49(6), 1417. doi: 10.2307/1911408

Nilsson L. 1999. Two-way trade between unequal partners: The EU and the developing countries. Weltwirtschaftliches Archiv, 135(1), 102-127. doi: 10.1007/bf02708161

Oguledo V, Macphee CR. 1994. Gravity models: a reformulation and an application to discriminatory trade arrangements. Applied Economics, 26(2), 107-120. doi: 10.1080/00036849400000066

Olivero MP, Yotov YV. 2012. Dynamic gravity: endogenous country size and asset accumulation. Canadian Journal of Economics/Revue canadienne d'économique, 45(1), 64-92. doi: 10.1111/j.1540-5982.2011.01687.x 
Pedroni P. 1999. Critical values for cointegration tests in heterogeneous panels with multiple regressors. Oxford Bulletin of Economics and statistics, 61(S1), 653-670.

Phillips PC, Perron P. 1988. Testing for a unit root in time series regression. Biometrika, 75(2), 335-346.

Pöyhönen P. 1963. A tentative model for the volume of trade between countries. Weltwirtschaftliches Archiv, 93-100.

Rostow WW, Lewis WA. 1979. The Evolution of the International Economic Order. The American Historical Review, 84(1), 106. doi: 10.2307/1855662

Sapir A. 2001. Domino effects in Western European regional trade, 1960-1992. European Journal of Political Economy, 17(2), 377-388.

Silva JMCS, Tenreyro S. 2006. The Log of Gravity. Review of Economics and Statistics, 88(4), 641-658. doi: 10.1162/ rest.88.4.641

Silva JS, Tenreyro S. 2010. On the existence of the maximum likelihood estimates in Poisson regression. Economics Letters, 107(2), 310-312.

Soloaga I, Alan Wintersb L. 2001. Regionalism in the nineties: what effect on trade? The North American Journal of Economics and Finance, 12(1), 1-29. doi: 10.1016/ s1062-9408(01)00042-0

Thursby JG, Thursby MC. 1987. Bilateral Trade Flows, the Linder Hypothesis, and Exchange Risk. The Review of Economics and Statistics, 69(3), 488. doi: $10.2307 / 1925537$
Tinbergen J. 1962. Shaping the world economy; suggestions for an international economic policy.

Truman EM. 1972. The production and trade of manufactured products in the EEC and EFTA: A comparison. European Economic Review, 3(3), 271-290. doi: 10.1016/0014-2921(72)90008-6

Truman EM. 1972. The production and trade of manufactured products in the EEC and EFTA: A comparison. European Economic Review, 3(3), 271-290. doi: 10.1016/0014-2921(72)90008-6

Viner J. 2014. The Customs Union Issue: Oxford University Press (OUP).

White H. 1980. A heteroskedasticity-consistent covariance matrix estimator and a direct test for heteroskedasticity. Econometrica: Journal of the Econometric Society, 817-838.

WTO. 2015. Regional trade agreements. Retrieved 10/2/2015, from wto http://www.wto.org/english/ tratop_e/region_e/region_e.htm

Yeats AJ. 1998. Does Mercosur's Trade Performance Raise Concerns about the Effects of Regional Trade Arrangements? The World Bank Economic Review, 12(1), 1-28. doi: 10.1093/wber/12.1.1

Zidi A, Dhifallah SM. 2013. Trade Creation and Trade Diversion between Tunisia and EU: Analysis by Gravity Model. International Journal of Economics and Finance, 5(5). doi: 10.5539/ijef.v5n5p131 